\title{
İmparatorluğun Ontolojik Grameri versus Ulus-Devletin İdeolojik Mantığı
}

\author{
Mehmet Ulukütük*
}

Öz

Bu makalede imparatorluk ve ulus-devlet gramer ve mantık metaforundan hareketle yeniden yorumlanmaya ve tahayyül edilmeye çalışılmaktadır. Gramer ve mantık metaforları bir imkâna ve zorunluluğa işaret edecek şekilde kullanılmaktadır. Söz konusu metaforun kendisini inşa ettiği zemin ise ontoloji ve ideoloji olmaktadır. Buna göre imparatorluk ontolojik bir gramer olarak tahayyül edilmiş, farklılık, derinlik, otantiklik, adalet, liyakat, esneklik, gelenek, hetorejenlik ve kozmopolitlik kavramları ekseninde de facto bir durum olarak tahayyül edilmiştir. Diğer yandan ulus-devlet ise, benzerlik, eşitlik, yapaylık, elitlik, katılık ve homojenlik kavramları ekseninde a priori bir zorunluluk dayatması olarak tasavvur edilmiştir. İmparatorluktan ulus-devlete geçişin bir ufuk ve eksen küçülmesi, felsefi olarak ontolojiden kopuşu, sosyolojik olarak milletten kitleye geçişi, ekonomik olarak paylaşımcı ve dayanışmacı yapıdan sermayenin merkezileştiği bir kapitalist sisteme dönüşü, etik olarak adaletten ayrılışı, politik olarak ise milletten etno-seküler ulusçuluğa geçişi temsil ettiği gösterilmeye çalışılmıştır.

Anahtar Kelimeler: İmparatorluk, Ulus-devlet, Mantık, Gramer, Ontoloji, İdeoloji.

\section{Ontological Grammar of the Empire Versus The Ideological Logic of The Nation-State}

\section{Abstract}

In this article, the empire and nation-state are tried to be reinterpreted and imagined from the metaphors of grammar and logic. Metaphors of grammar and logic are used to indicate an opportunity and necessity. Ontology and ideology are the basis on which this metaphor builds itself. Accordingly, the empire was envisioned as an ontological grammar and was positioned as a de facto situation on the axis of the concepts of difference, depth, authenticity, justice, merit, flexibility, tradition, heterogeneity and cosmopolitanism. On the other hand, the nation-state is positioned as an a priori imposition of necessity on the axis of similarity, equality, artificiality, elitism, rigidity, and homogeneity. The transition from empire to nation-state was demonstrated to represent its philosophical break from ontology, the sociological transition from the milla to the mass, the return from the economically sharing and solidarity structure to a capitalist system where capital is centralized, ethically its divergence from justice, and the political shift from nation to an ethnical secular nationalism.

Keywords: Empire, Nation-state, Logic, Grammar, Ontology, Ideology.

*Doç. Dr., | Bursa Teknik Üniversitesi | mehmet.ulukutuk@btu.edu.tr ORCID: 0000-0002-9694-1344 | DOI: 10.36484/liberal.605860

Liberal Düşünce Dergisi, Yıl: 24, Sayı: 95, Yaz 2019, ss. 67 - 86. Gönderim Tarihi: 17 Ağustos 2019 | Kabul Tarihi: 27 Ağustos 2019 


\section{Giriş̧}

Tarihte imparatorluklar ve ulus-devletler olmuştur. Ama imparatorlukların arkasında imparatorluk kavramı, ulus-devletlerin arkasında ulus-devlet kavramı vardır. Bu makalede imparatorluklardan değil, imparatorluktan söz edilecek, ulus-devletlerden değil, ulus-devletten söz edilecektir. Zaman zaman bazı imparatorluklara atıfta bulunulacaksa da, asıl meselemiz bir kavram olarak imparatorluk olacaktır. Olgusal ve tarihsel içerikten ziyade kavramsal ve tahayyüle dayalı bir soruşturmanın merkezde olduğu makalemizde gramer ve mantık, imparatorluk ve ulus-devlet kavramlarını tahayyül ederken başvurduğumuz birer metafor olacaktır. ${ }^{1}$ Gramer ve mantık biri dilin diğeri de düşüncenin kurallarını belirleyen birer aygıt olarak karşımıza çıkarlar. Dilin mantığı gramer, düşünmenin grameri ise mantıktır. Ancak mantığın pratikten bağımsızlığı, gramerin ise bizzat pratiğin teorisi olması hasebiyle birbirinden farklılaşmaktadır. Bu anlamda ulus-devlet, kurgusal bir olguya imparatorluk ise yaşayan bir geleneğe referansta bulunur.

Gramer ve mantık kavramları imparatorluk ve ulus-devlet kavramları ile beraber kullanılamayacak kadar uzak ve alakasız görünebilir. Ancak eğer dünyayı dil aracılığıyla kuruyorsak ve mesela Richard Rorty’ın önerdiği gibi varolan "sözcük dağarı" ile sınırlı kalmayarak ve kendi "sözcük dağarını" oluşturmak, gerçekte kişinin ya da toplumun kendini yaratma süreci ile ilişkili ise o zaman ifade etmek istediklerimizi yeni metaforlar eşliğinde yeniden tasavvur etmemiz, yeni bir dil kurmamız zorunlu bile olabilir. Birer metafor olarak kullanıldığında imparatorluk ve ulus-devlet arasındaki farkları daha iyi kavramamıza yardımcı olabilirler. Söz konusu metaforik kurguya göre imparatorluk, ontolojik bir gramer, ulus-devlet ideolojik bir mantıktır. Mantık benzerlik, tutarlılık, zorunluluk, gramer farklılık, çeşitlilik ve olumsallık demektir.

Aristo mantığı değişmeden iki bin yıldan fazla egemen oldu, ama gramer hep değişti. Hem kendi içinde değişti, hem milletten millete değişti. Çünkü her gramer bir imkân, her mantık ise bir icattır. İdeoloji bir icat, ontoloji bir imkândır. Ontoloji kuşatır, ideoloji böler. İmparatorluktan ulus-devlete geçiş gramerden mantığa geçiş demektir. İmkândan icada, farklılıktan benzerliğe geçiş. Bunun için dünya ölçeğinde her imparatorluğun ayrı bir hikâyesi, bütün

1 Gramerin bir metafor olarak kullanımına örnek bazı çalışmalar için bkz. Harold, J. Laski, A Grammar of Politics, London: Allen \& Unwin, 1925; Ulukütük, Mehmet, “Dinin Grameri versus Felsefesinin Mantığı: İslam Düşüncesinde Dinî ve Felsefî Epistemeler Gerilimin Mantıksal ve Gramatik Temelleri”, İnönü Üniversitesi İlahiyat Fakültesi Dergisi [Mesned Ilahiyat Araştırmaları Dergisi], cilt: III, sayı: 2, s. 135162; Negri, Antonio, Porselen Yapımı Politikanın Yeni Bir Grameri İ̧in, çev.: Elyasa Koytak, Monokl Yayınları, İstanbul 2013.

2 Richard Rorty, Olumsallık, İroni ve Dayanışma, çev. Mehmet Küçük - Alev Türker, Ayrıntı Yayınları, İstanbul, 1995, s. 31. 
ulus-devletlerin ise tek-tip bir karakteri vardır. İmparatorluk de facto farklılık, ulus-devlet a priori benzerliktir. Ulus-devletin sahneye çıktığı dünyanın Descartes ve Newton'un tasarladığı, kişilerin iradelerinden bağımsız, kendi kendine işleyen mekanik bir dünya, de jure ve kurgusal bir karakter kazandığı dünya olması devleti bir iktidar makinasına dönüştürmüştür. Bu iktidar makinası, devlet, ulus ve toplum gibi soyut varlıklar icat etti. ${ }^{3}$ Soyut varlıklar, mantıksal dünyanın varlıklarıdır, tarihten ve toplumdan soyutlanmıştır. Makine gibi işleyen bu dünyanın insanlarının yaşamından söz edilebilir ama hayatından söz etmek mümkün değildir. Zira ulus-devletin ortaya çıkışından sonra devlet iradesi görünmez hale gelmiştir. ${ }^{4}$

\section{İmparatorluğun Gramatik Penceresi Ulus-Devletin Mantıksal Aynası}

Mantık etimolojik olarak nutuk, yani konuşma demektir. İç konuşmaya mantık, dış konuşmaya gramer denir. Gramer bir pencere gibi bize dışarıyı gösterir. Mantık bir ayna gibi iç konuşmamızı yansıtır. Ulus-devlet ayna misali içe, imparatorluk pencere misali dişa yöneliktir. Ulus-devlet her yerde ve zamanda içeriye dairdir. Dostu da düşmanı da içeridedir. İmparatorluğun dostu da düşmanı da dışarıdadır. İmparatorluğun halklarının birbirleri arasında özellikle ne dostu ne de düşmanı vardır. Her şey mümkündür. Ulusdevlette dost da düşman da belirlenmiştir. Her şey mekaniktir. A prioridir. İmparatorlukta de facto her şey mümkündür. Bu anlamda imparatorluğun peri ferisinin siyasi ve uygarlık düzeyi bakımından farklı ölçüde gelişmesi, devletlerde, özellikle de ulus-devletlerde görülmeyen, temelde imparatorluklara özgü bir sorundur. Ulus-devletler diğer ülkeler karşısında ayakta durabilmek için güç ve nüfuzlarını aldıkları nispeten bütünsel bir siyasi-kültürel kimlik oluştururken, imparatorluklar aslında farklı devletlerarasında yaşanan çelişki ve çatışmaları kendi içlerinde yaşamak, bunları ya kendi lehlerine çevirmek ya da bu yüzden çökmek zorundadır. ${ }^{5}$

Çünkü imparatorluk özelliği gösteren devletlerin yegâne meselesi dış ilişkilerdir. Ulus-devletlerin tek meselesi ise, iç işleridir. Bu aslında devletin asli görevinin ne olduğu sorusuna mevcut tahayyüle göre bir cevap bulma meselesidir. Mesela Carl Schmitt'e göre devletin asıl görevi, "Kendi egemenlik alanında 'huzur, güven ve düzeni' sağlamak, bu yolla hukuk normlarının geçerliliği

3 Bedri Gencer, İslam'da Modernleşme 1839-1939, Doğu Batı Yayınları, Ankara, 2012, s. 642.

4 Kojin Karatani, Dünya Tarihinin Yapısı @ Üretim Tarzlarından Mübadele Tarzına, çev. Ali Karatay, Metis Yayınları, İstanbul, 2019, s. 244.

5 Hefried Münkler, İmparatorluklar Eski Roma'dan ABD’ye Dünya Egemenliğinin Mantığı, çev. Zehra Aksu Yılmazer, İletişim Yayınları, İstanbul, 2009, s. 105. 
için önkoşul niteliğindeki normal durumu tesis etmektir." ${ }^{\circ}$ Schmitt, devletin huzuru sağlama görevini yerine getirmesinin "iç düşman"1 tespit etmeyi gerekli kıldığını savunur.7 Schmitt’in burada siyasal birlikten kastı, ulusal devlettir. Oysa imparatorluğun Gazali ve İbn Teymiye gibi düşünürlerinin temel endişesi, siyasal birliği korumak değildir. "Siyasal birlik içindeki iç savaşı önlemektir." Zira onların devlet tahayyülü, imparatorlukla karakterize edilen bir nizâm-1 âlem arayışıdır. Çünkü "nizâm kavramında, coğrafi ve ulusal sınırları aşan, onları önemsizleştiren "iç" ve "dış” 1 bir bütün olarak algılanması ve insanı/âlemi birleştiren bir nitelik bulunmaktadır." ${ }^{9}$

İmparatorluğun bir gözü ve bir kulağı daima dışarıdadır. İmparatorluk kendi dışındaki dünyaya bitmek tükenmez bir meraktır. Bu merakın en mütecessim hali ise tercümedir. İmparatorluk demek tercüme demektir. Dokuzuncu yüzyılın başlarına bu noktadan bakmak, Me'mûn'un, antik bilimsel ve felsefi literatürün Arapçaya tercüme edilmesini şevkle destekleyerek, İslam monoteizminin püriten versiyonunu vurgulayan dinsel bir siyaset yürürlüğe koyarak ve Bizans'a karşı biteviye askeri saldırılar düzenleyerek nasıl bir imparatorluk kültürü oluşturmaya çalıştığını daha iyi anlamamıza yardımc1 olur. Me'mun'un tercüme faaliyetlerini desteklemedeki dinamizmi, kendi imparatorluk kültürünün bir parçası olabilsinler diye, yabancı bilimleri İslami hassasiyetlerle kaynaştırma niyetini yansıtır. ${ }^{10}$ Abbasiler'in, yazılı ya da sözlü, seküler ya da dini-ilahi hikmete popüler ve ilmi ilginin giderek arttığı bir ortamda antik bilgiye ilgi göstermesi, Me'mûn'u, bir imparatorluk kültürü geliştirmek ve hilafeti geçmiş büyük imparatorlukların bir mirasçısı ile monoteizmin savunucusu olarak ön plana çıkarmak amacıyla tercüme faaliyetlerini desteklemeye yöneltmiştir. ${ }^{11}$

6 Carl Schmitt, Siyasal Kavramı, çev. Ece Göztepe, Metis Yayınları, İstanbul 2006, s. 65.

7 Schmitt, a.g.e., s. 65.

8 Orhan Keskintaş, Adalet, Ahlak ve Nizam Osmanlı Siyasetnameleri, ỉletişim Yayınları, İstanbul, 2017, ss. 65-66.

9 Keskintaş, a.g.e., s. 92-93. Nizâm ve nizâm-ı alem kavramlarının analizi için bkz. Görgün, Tahsin, “Osmanlı'da Nizâm-ı Âlem Fikri ve Kaynakları Üzerine Bazı Notlar”, İslâmî Araştırmalar, 2000, cilt: XIII, sayı: 2, ss. 180-188.

10 Hayrettin Yücesoy, Ortaçağ İslam’ında Mesihçi İnançlar ve Imparatorluk Siyaseti Dokuzuncu Yüzyılın Başlarından Abbasi Hilafetine Kadar, çev.: Ahmet Demirhan, Klasik Yayınları, İstanbul, 2016, s. 23. İslam düşüncesindeki tercüme faaliyetlerinin hermeneutik ve bibliyografik bir değerlendirmesi için bkz. Mehmet Ulukütük, “İslam Düşüncesinde Tercüme Faaliyetleri: Hermeneutik ve Bibliyografik Bir Katkı", İönü Üniversitesi, İlahiyat Fakültesi Dergisi, [Mesned İlahiyat Araştırmaları Dergisi], Sayı:2, YIl:1, 2010, ss. 249-288.

11 Yücesoy, Ortaçağ İslam’ında Mesihçi Inançlar ve Imparatorluk Siyaseti, s. 189. Dimitri Gutas da tercüme ile imparatorluk arasında doğrudan bağlar kurar. Ona göre iktidarda kalmak isteyenlerin mutlaka tercüme stratejisine başvurmuşlardır. Abbasi Hanedanlığı bunun en tipik örneğidir. Edward Said'den iktibasla, "Biraz da imparatorluk nedeniyle bütün kültürler iç içe geçmiştir, hiç biri tek ve katışıksız değildir" tespitini yaparak imparatorluğun en tipik karakteri olan iç içe kültürlerin yaratıcısının tercüme olduğunu iddia eder. Bkz. Arapça Düşünce Yunanca Kültür Bağdat’ta Yunanca-Arapça Çeviri Hareketi ve Erken Abbasi Toplumu, çev.: Lütfi Şimşek, Kitap Yayınları, İstanbul, 2003, s. 179. 
Hüsamettin Arslan'ın deyişiyle, “insan tercümeyle, başka dünyalara açılır. Tercüme ötekiyle, farklı olanla, bize benzemeyenle diyalogdur. Büyük tarihsel entelektüel dönüşüm süreçlerinin arka bahçesinde büyük tercüme hareketleri vardır. İslam düşüncesinin sekiz ve onbirinci yüzyıllar arasındaki çiçeklenişini ve Rönesans'ı düşünün. Tercüme bizi nispeten homojen kendi entelektüel dünyamızdan kurtarır ve düşüncede kozmopoliteye açar. Kozmopoliteye açılmak, farklı düşüncelere ve bakış açılarına ve söylemeye bile gerek yoktur ki, başka dillere ve dünya görüşlerine açılmaktır. Düşünce ve düşünür yalnızca kozmopolit düşünce iklimlerinde doğabilir. Düşüncenin gübresi farklılıktır; homojenite değil."12 İmparatorluk heterojen, ulus-devlet homojendir. İmparatorluk beraber yaşama, ulus-devlet birlik içinde bir yaşamadır.

İmparatorluk ulus-devletin aksine içe kapanma değil bitmek bilmeyen bir iştiyak ile hep bir dışa açılma arzusudur. Zira içe kapandıkça homojeni dışa açıldıkça heterojen olunur. Düşüncenin, yaratıcılığın, farklılığın gübresi ise içe gözünü kapatmadan dışarıya açılmaktır. Zira dışarısı diye bir şeyden söz etmek ancak bir içerisi diye bir şey söz konusu ise anlamlı olabilir. Bununla birlikte sadece heterojenliğin olduğu yerde imparatorluk tahakkuk edebilir. Bu cümleden olmak üzere imparatorluğun heterojen karakteri evlenme usulünde de kendini gösterir. Ş. Teoman Duralı söz konusu durumu şöyle dile getirir: “'İçeridenevlenme’ zorunluluğunu taşıyan kabileler yahut aşiretlerden neşet etmiş milletler, 'ülkü toplumu'nda devletleşme evrelerinin en olgun, en mütekâmil aşaması demek olan imparatorluğu hiçbir zaman tam anlamıyla gerçekleştirememişlerdir. Kadim kabile ile aşiret iytikatları gereği, 'dışarıdan evlenme' zorunluluğuna bağlı Türkler, özellikle Müslüman olduktan sonra, imparatorluk kurma hünerlerini geliştirmiş, nihayet Osmanlı Devletiebedmüddetiyle bu maharetlerini doruğa ulaştırmışlardır." ${ }^{13}$ Bunun içindir ki; "tarihte soyca en ziyade karışmış iki imparatorluk milletinden biri Türklerse, öbürü de İspanyollardır. ${ }^{14}$ Tarihte şu ya da bu imparatorluğun içeriden evlenme ya da dışarıdan evlenme usulüne uyup uymadığı, dışarıdan evlenme usulü sayesinde büyüdüğü veya küçüldüğü ayrı bir konu olmakla birlikte imparatorluk olmanın bizatihi kendisinden söz edebilmenin yolu daima dışarıya açılmaktan geçtiğini söyleyebiliriz. Dışarıdan evlenme eğer dışarıya açılmak anlamına geliyorsa o zaman imparatorluk olmanın zorunlu şartlarından birisi olarak görülebilir.

12 Hüsamettin Arslan, “Mütercimin Önsözü”, Insan Bilimlerine Prolegomena, der-çev. Hüsamettin Arslan, Paradigma Yayınları, İstanbul, 2002, s. 3.

13 Ş. Teoman Duralı, Çağdaş Küresel Medeniyet Anlamı, Gelişimi Konumu, Dergâh Yayınları, İstanbul, 2016, s. 128.

14 Duralı, a.g.e. s. 129. 
İmparatorluğun dışarısıyla ilgisiz aslında özü itibariyle dışarının kendisine değil, dışarı sayesinde kozmopolitan ve çoğulcu olması sebebiyledir. Çünkü “tarihsel gerçeklik olarak imparatorluk, kültürel, etnik, ekonomik ve toplumsal açılardan çeşitlilik arz eden farklı halkları bünyesinde toplayan bir büyük politik ve teritoryal gövde olarak" tasavvur edilir. ${ }^{15}$ Bunun yanında imparatorluk çoğulculuğa işaret etse de sinırları sadece “uzaktaki öteki”ler üzerinden çizilmez. Zira ulus-devletin vaz ettiği şekliyle birey, vatandaş, kültür, kimlik tanımları en az diğer unsurlar kadar belirleyici bir niteliğe sahip. Aslında günümüz çoğulculuk söylemleri, ulus-devletin kendini koruma altına alma güdüsünün ve kompleksinin bir sonucu olarak çıkıyor karşımıza. Bu yüzden çoğulculuğu bir tehdit olarak görenler de bir kurtuluş reçetesi olarak değerlendirenler de temel bir yanılgı içine düşmekten kurtulamıyorlar. Çünkü çoğulculuğun bir tehdit olabilmesi için bir toplumun zaten baştan zayıf ve bölünmüş olması gerekir. Ancak farklı görüşlere açık olmak, farklı yaşam biçimlerine saygı göstermek evvel emirde bir özgüven meselesidir. Bu açıdan bakarsak "kozmopolit kültürler"in gücü ve yaratıcı enerjisi ve aurası bu özgüvenden neşet ediyor. Fakat ulus-devletin tehdit algısı bireylerin özgürlük arayışının ve toplumun derin irfanının hep önüne set çekiyor. Zira ulus-devletin hâkim yapısı, homojen bir toplumsal düzen ve kontrol mekanizması kurmaktır. Ulus-devlette bireysel farklılıklar, kültürel gelenekler, dini yapılar, cemaatler, vs. bu homojenliğe gölge düşüren unsurlar olarak değerlendirilir. ${ }^{16}$ Her türlü farklılıktan kurtulmanın yolunu aramaktan vazgeçmez. Ulus-devlet çoğulculuğa a priori olarak imkân vermez. Homojenize bir kültürün ve kurgusal bir geçmişin gölgesinde bütün farklılıkları aynileştirmeye çalışır. İdeolojik bir mantık olarak dayatmacı ve buyurgan tavrını varoluşunun temeli olarak görür.

Gramer olarak imparatorluk gramatik doğası gereği dayatmadan kaçınır. Çünkü gramer kurallarını konuşanlara dayatmaz, konuşanların, konuşurken dikkat ettikleri kural olur. Hiçbir dil işe gramer oluşturmakla başlamaz, önce konuşur, sonra konuşmalardan gramer de facto zuhur eder. Çocuklar dile, grameri öğrenerek başlamaz, önce dinler, dinler sonra konuşur, konuşur ve en sonunda de facto grameri keşfeder. İmparatorluk bir şey dayatmaz, dinler, dinler sonra konuşur ve en sonunda konuşmalardan de facto kurallar çıkar. Ulus-devlet yeni yeni konuşmaya çalışan çocuklara gramer altında bir mantık dayatmadır. Önce mantıksal grameri öğretir, konuşma ardından gelir. Zira mantıksal gramer olmadan konuşmasından korkar. Korkusu ona ideolojik aygitlar üretmesine zorlar. Okul, hastane ve hapishane bu korkunun bir eseridir. ${ }^{17}$

15 Barış Ünlü, “İmparatorluk Fikrinin Gelişimi”, Ankara Üniversitesi, Siyasal Bilgiler Fakültesi Dergisi, Cilt:65, Sayı:3, 2012: 238.

16 İbrahim Kalın, Akıl ve Erdem Türkiye’nin Toplumsal Muhayyilesi, Küre Yayınları, İstanbul, 2013, s. 250.

17 Bkz. Louis Althusser, İdeoloji ve Devletin İdeolojik Aygıtları, çev.: Yusuf Alp, Mahmut Özışık, İletişim Yayınları, İstanbul, 2002, ss. 32-38. 
Gramer etimolojik olarak grammar'dan gelir büyü demektir. ${ }^{18}$ Her imparatorluk büyüleyicidir. Ulus-devlet ise büyüden arındırılmış dilbilgisidir. Büyü etkileyici, dilbilgisi sıkıcıdır. Bunun için bütün ulus-devletler sıkıcıdır. Her ulus-devlet tecrübesi can sıkıcı, her ulus-devlet devrimi can yakıcıdır. İmparatorluk gramer yoluyla bir dil oyunu kurmak demektir. Kendi dansının oyununu keşfetmektir. Kendini keşfetmektir. Kendi oyununa dönmektir. Ama oyunun, oyun olduğunu bildiğinizde ve onu yalnızca bir oyun olarak anladığınızda o, artık oyun olmaktan çıkar. En iyi oyun, oyun olduğu fark edilemeyen oyundur. ${ }^{19}$ Oyun sadece oyun değildir, çünkü kuralları vardır ama oyun kurallar için değil, kurallar oyun içindir. İmparatorluk oyun için kurallar koyar, ulus-devlet kurallar için oyun tasarlar. İmparatorluk bir oyun kurma, ulus-devlet oyunu kurallara göre oynamaya çalışmaktır. Kuralları aklından hiç çıkaramadığı için de hiçbir zaman gerçek anlamda bir oyun kuramaz. Sadece oyuncu kalabilir, kurmadığı, kuramadığı aslında seyircisi olduğu oyunların figüran oyuncusu.

\section{Ontoloji Olarak İmparatorluk Epistemoloji Olarak Ulus-Devlet}

İmparatorluktan ulus-devlete geçiş, ontolojiden epistemolojiye geçiş demektir. Felsefe tarihinde ontoloji öncelikli bir felsefe yerine epistemoloji öncelikli bir felsefenin zuhuru ile ulus-devletin icadı arasındaki var olan ilişki şimdiye kadar kimsenin dikkatini çekmediyse eğer bunun nedeni epistemolojinin çocukları olmamızdandır. Ama epistemoloji bizi bedenen/tensel var etse bile ruhumuza/tinimize üfleyen imparatorluktur. Bunun için hatırlayarak millet ya da imparatorluk, unutarak ulus ya da ulus-devlet oluruz. ${ }^{20}$ Ulus trajik bir unutkanlık, imparatorluk büyüleyici bir hatırlamadır. İnsanoğlunun dünya yazg1sında başına gelebilecek en büyük felaket ne küresel iklim değişiklikleri, ne ekonomik istikrarsızlık ne de yaşanan sağlık sorunlarıdır. En büyük felaketimizi unutma, unutkanlık ve unutulmuşluktur. İmparatorluk sadece siyasi bir rejim nostaljisi ya da özlemi değil, hatırlayarak varoluşumuzu inşa edeceğimiz ontolojimizdir. Ulus-devletler bize unutmayı salık verirler. Unutmak tarihten kurtulmak, millet ve imparatorluk olmanın yükünden kurtulmak demektir. Mesela “Türk olmaktan nasıl kurtulunur sorusunun cevabı Türk tarihinden kurtularak olacaktır. Bu nasıl sağlanır? “Türk milletini içerik itibarıyla yapaylaştırarak yani tarihsizleştirerek. Her milletin doğal yeri tarihidir. Bir milletin doğal yerini bulması, o milletin özünün gürleşmesini, özgürleşmesini sağlar.

18 Barry Sanders, Kahkahanın Zaferi Yıkıcı Tarih Olarak Gülme, çev.: Kemal Atakay, Ayrıntı Yayınları, İstanbul, 2001, ss. 39-40.

19 “En iyi ideoloji, ideoloji olduğu fark edilmeyen ideolojidir. Türkiye Cumhuriyetinin ideolojisi ‘En iyi ideolojiyim’ diye bağırıyor." Arslan, Hüsamettin, Jöntürkler, Jönkürtler ve Muhafazakârlar Meçhul Okurla Söyleyiş̧iler, Paradigma Yayınları, İstanbul, 2012, s. 99.

20 Mustafa Özel, Roman Diliyle Siyaset, Küre Yayınları, İstanbul, 2018, s. 41. 
$\mathrm{Bu}$ nedenle her millet eğitim ve terbiye sistemini, doğal yerini verecek bir biçimde örgütlemelidir. Aksi takdirde, millet yapay yerde yapaylaşır; bir süre sonra da iç-çatışmaya yuvarlanır." ${ }^{21}$ Unutmak ulus olmanın patolojik mottosu, hatırlamak /tezkire millet ve imparatorluk olmanın sine qua nonudur.

Ulus-devletin filozoflarının meselesi epistemoloji, imparatorluğun filozoflarının meselesi ontolojidir. Ontolojiyi meselesinin merkezine yerleştirmiş her filozof imparatorluğun filozofudur. Epistemoloji felsefesinin merkezine yerleştirmiş her filozofun kaderi ise ulus-devletin filozofu olmaktır. Descartes, Bacon, Hume, Kant bir ulus-devlet filozofudurlar. Sadece kendi anadillerinde yazdıklarından değil, ontolojisiz bir epistemolojiyi halklarının yegâne meselesi haline getirdikleri içindir sebebi. Farabi, İbn Sina, Gazzâlî, İbn Rüşd imparatorluğun filozoflarıdır. Sadece Arapça yazdıkları için değil, ontolojiyi halklarının olmazsa olmaz meselesi haline getirdikleri içindir sebebi. İmparatorluğun filozofları nizam-ı âlemi, ulus-devletin filozofları vatanın bölünmez bütünlüğünü dert edinirler. Nizam-1 âlem bir imkân ve meydan okuma, vatanın bölünmez bütünlüğü bir korku ve imparatorluklara bir cevap verme teşebbüsüdür. İmparatorluk nizam-1 âlem olmadan vatanın bütünlüğünün düşünülemeyeceğini iddia eder. Ulus-devlet nizam-1 âlemde tek sığınağının vatan olduğunu zanneder. Vatan üzerine israr ettikçe, nizam-1 âlemden bigâne kalır.

Osmanlı imparatorluğundaki Türk Felsefesi ile Cumhuriyet dönemi Türk düşüncesi arasındaki farkın bizi yönlendireceği adres bu gerçeği yakından görmek için doğru adreslerden birisidir. Osmanlı felsefesinin kurucularından Dâvûd-i Kayserî’nin Matla'u husûsi'l-kelim fî me'ânî Fusûsi'l-hikem (Varlık ve Onun Hak Olduğu Hakkında), Esâsü'l-vahdâniyye ve mebne'l-ferdâniyye (Birlik ve Çokluğun Mâhiyeti Hakkında), 'Aynü'l-a'yân (İdrâkin Hakikatleri, Bölümleri ve Yollar Üzerine Tembih), Nihâyetü'l-beyân fi dirâyeti'z-zemân (Zamanın Mâhiyeti ve Hakikati Hakkında), Molla Fenârî'nin Misbâhu'l-üns beyne'l-ma'kûl ve'l-meşhüd fi şerhi Miftâhi'l-gayb (Hakkın Varlığının Tasavvuru ve Sübûtuna İşaret), Yanyalı Esad Efendi'nin, Risâletü'l-Lâhûtiyye Hocazâde'nin Tehâfütü'l-felâsife, Kemalpaşazâde'nin Risâle fî Tahkîki'l-hakki fi'l-mes'eleti'l-kâile hel yecûzü en yestenide'l-kadîmü'l-mümkin ile'l-müessir em lâ (Mümkün Bir Kadîm Varlığın Müessire Dayanmasının İmkânına Dair Bir İnceleme) Nihâyetü'l-beyân fi dirâyeti'z-zemân (Zamanın Mâhiyeti ve Hakikati Hakkında), Taşköprüzâde'nin Risâletü'ş-Şuhûdi'l-'aynîfî mebâhisi'l-vücûdi'z-zihnî (Zihinsel Varlığa Dair Tartışmalarda Özün ve Hakikatin Tespiti), Çerkeşîâ̂de Mehmed Tevfik Efendi'nin Risâle fî Kevni'l-mâhiyyât mec'ûleten (Mâhiyetlerin Yaratılmış (Mec'ûl) Olup Olmadığına

21 İhsan Fazlığlu, Akıllı Türk Makul Tarih, Papersense Yayınları, İstanbul, 2014, s. 14. 
Dair) ve Risâle fi'l-'Akl (Akla Dair) adlı eserler ${ }^{22}$ bir yandan İslam metafiziğinin gölgesinde icra edilen felsefenin birer meyveleri bir yandan da kendinden önceki İbn Sînâcı geleneğin varlık problemlerini tartışmakla birlikte vahdet-i vücûd dâhil Osmanlı felsefelerinin bir resmi gibidir. Bu eserler ve adını burada sayamayacağımız diğer eserler İmparatorluğun felsefi gündemini belirleyen eserlerdir. Varlık'ı var olduğu haliyle anlamaya, keşfetmeye yönelik bir çabanın ürünüdür. ${ }^{23}$

Ulus-devletin Cumhuriyetinde ontoloji merkezli felsefe yerini, Bergsonculuğa ${ }^{24}$, pozitivizme ${ }^{25}$, materyalizme ${ }^{26}$ ya da spritüalizme ${ }^{27}$ bırakmıştır. Daha doğru bir ifade ile belli başlı bütün ideolojilere, izmlere maruz kalmıştır. Ancak bu izmler ulus-devlet gibi Cemil Meriç'in ifadesiyle birer deli gömleği fonksiyonunu yerine getirmiştir. Bizim dışımızdaki düşünce iklimlerine kanat açmak başka bir şey, başka iklimlerden gelen bulutların oluşturduğu gölgelerin karaltısında bocalamak başka bir şeydir. Başka iklimlerde oluşan düşüncelerle karşılaşmak bir özgüven meselesidir. Onunla yüzleşmeyi ve hesaplaşmayı gerektirir. Hem hesap sorabilmeyi hem de hesap verebilmeyi içeren hesaplaşma köksüz düşüncelerin üstesinden gelebileceği bir şey değildir. Emperyalizm sadece hesap sormayı, ulus-devlet sadece hesap vermeyi, imparatorluklar ise hesap sorma ve hesap verme diyalektiğini hem senkronik hem de diyakronik bir şekilde gerçekleştirirler. Mesela yukarıda bahsettiğimiz Abbasi, Selçuklu ve Osmanlı imparatorluklarında bir yandan Yunancadan felsefi, bilimsel ve pratik hikmete dair tercümeler yapılırken bir yandan da Tehâfütü'l-felâsife kaleme alınmış, hatta Tehâfütü't-Tehâfüt dahi yazılabilmiştir. Ulus-devlet çatısı altında her türden ideolojiye maruz kalanlar, maruz kaldıkları şeylerle ya bir aşk ya da bir nefret ilişkisi yaşamalarına rağmen hiçbir zaman onları yapısöküme ${ }^{28}$ uğratabilecek bir tehâfüt yazmayı tahayyül bile edememişlerdir.

22 Osmanlı felsefesi ile ilgili daha geniş bir resim için bkz. Alper, Ömer Mahir, Osmanlı Felsefesi Seçme Metinler, Klasik Yayınları, İstanbul, 2015. Demir, Remzi, Philosophia Ottomanica Osmanlı Imparatorluğu Dönemi'nde Türk Felsefesi, (Eski Felsefe), cilt: I, Lotus Yayınları, Ankara 2005; Fazlıoğlu, ỉhsan, Kayıp Halka İslam-Türk Felsefe-Bilim Tarihinin Anlam Küresi, Papersense Yayınları İstanbul, 2014; Derin Yapı İslam-Türk Felsefe-Bilim Tarihinin Kavramsal Çerçevesi, Papersense Yayınları, İstanbul, 2014; Nazari Ufuk İslam-Türk Felsefe-Bilim Tarihinin Zihin Penceresi, Papersense Yayınları, İstanbul, 2016.

23 Bkz. Mehmet Ulukütük, “Çağdaş Türkiye'de Felsefenin Osmanlıcasını Keşfetmek: Bir Literatür Değerlendirmesi”, Muhafazakâr Düşünce Dergisi, Yıl: 15, Sayı: 54, 2018, ss. 201-228.

24 Levent Bayraktar, “Bergsonculuğun Türkiye’ye Girişi ve İlk Temsilcileri”, Felsefe Dünyası, Sayı: 28, 1998, ss. 62-72.

25 Bkz. Murtaza Korlaelçi, Pozitivizmin Türkiye’ye Girişi, İnsan Yayınları, İstanbul, 1986.

26 Bkz. Mehmet Akgün, Materyalizmin Türkiye’ye Girişi, Elis Yayınları, Ankara, 2005.

27 Bkz. Neşet Toku, Türkiye'de Anti-Materyalist Felsefe -Spirütalizm Illk Temsilciler-, Beyan Yayınları, İstanbul, 1996.

28 Dermot Moran, “The Destruction of Destruction: Heidegger's Versions of the History of Philosophy”, ed. Karsten Harries, Christoph Jamme, Martin Heidegger: Politics, Art and Technology, Holmes\&Meier, New York, 1994, s. 175. 


\section{İmparatorluğun Adaleti versus Ulus-devletin Eşitliği}

Ulus-devlette eşitlik, imparatorlukta adalet arayışı vardır. Tarihte vücut bulmuş imparatorluklar adalet abideleri değildir elbet. Ama her imparatorluk âlem şümul bir adalet arayışıdır. Ulus-devlet ise kendini eşitlikte sabitler. Benzerlikler arasında eşitlik, farklılıklar arasında adalet tecelli eder. Adaletin olduğu yerde liyakat, eşitliğin olduğu yerde diğerlerinden daha eşit olan elitizm tezahür eder. Adalet liyakat, eşitlik elitizm demektir. Ulus-devletin elitleri, imparatorluğun ehilleri vardır. İmparatorluk işi ehline, ulus-devlet işi kendi elitine tevdi eder. Ehiller işini esneklikle, elitler işini enaniyetle yapar. İmparatorluk esnek bürokrasi, ulus-devlet enaniyetli teknokrasidir. Enaniyet ideokratik devletin varoluş koşuludur. "İdeokratik devlet kendisini bir "yüce" fikre, bir seküler "iman” ilkesine göre örgütleyen, muhatabı olan halkı bu fikir ya da iman ilkesine göre yöneten, dizayn eden devlettir. İdeokratik devletler muhatapları durumundaki mevcut halkları beğenmezler; idea'ya, seküler "yüce" norma, fikre ya da ideolojiye uygun "yeni” bir halk yaratmak isterler ve "halka zulüm” buradan doğar." ${ }^{29}$ Halka zulüm katılık demektir. Dediğim dedik anlayışıdır. Bu anlayışta olgular ve yasalar karşı karşıya geldiğinde olgunun ışığında yasalar değiştirilmez veya yeniden yorumlanmaz, yasaların gölgesinde olgular dizayn edilir. Esnekliğe asla yer yoktur. Esneme yeteneğinden mahrum “entite”nin kaderi ise kırılmaktır. Osmanlı imparatorluğu bu esneme kabiliyetine sahip olduğu için uzun yaşamıştır. Çünkü gelenek esnektir, esnemeyen şeyler ise geleneğe dönüşmez. ${ }^{30}$ Zira devletin işlevleri arttıkça kalıcı yapı ve süreçler değişir ve tavsiyeler de farklılaşır. Yapı ve süreçlerin belirleyicisi ise büyüklük ve devletin yerine getirmek zorunda olduğu işlevlerin sayısıdır. İmparatorlukta âdemi merkezi yapı ve yetki devri kaçınılmazdır. ${ }^{31}$ Zira esneklik yoksa hayat da yok demektir. Hayatın olmadığı yerde ise insan, olgular, tarih, toplum, gelenek, teamül değil, yasa, kanun, yönetmelik, bürokrasi ve dayatma vardır.

Hâlbuki esneme adalet demektir. ${ }^{32}$ Adalet ise tarihte kalıcı olmanın yegâne düsturudur. İhsan Fazlıoğlu Akıllı Türk Makul Tarih adlı eserinde adalet ile tarihte kalıcı olmak arasında bir rabıta kurar ve bu rabıtanın delili olarak İbn Haldun'u medlulü olarak da Osmanlı İmparatorluğunu gösterir: “Memlûklu

29 Hüsamettin Arslan, “Aydınlanmış Ulus-Devletten Demokratik İmparatorluğa”, Kritik Dergisi, Yıl: 1, Sayı: 8, 2016.

30 Arslan, Jöntürkler, Jönkürtler ve Muhafazakârlar, s. 97.

31 Ömer Dinçer, Siyasetnameleri Yeniden Okumak, Bir Yönetim Bilimci Gözüyle Geleneksel Siyasi Düşünce, Klasik Yayınları, İstanbul, 2018, s. 293.

32 Bkz. Kasım Küçükalp, “Ötekine Yönelik Etik Refleksiyonun İmkânı Olarak Adalet”, Ahlak ve Başkası Modern Felsefede ve islam Düşüncesinde Öteki, Ed. Lütfü Sunar \& Selami Varlık, Nobel Yayınları, İstanbul, 2017, ss. 61-87. 
meşhur âlim ve bürokrat İbn Haceri'l-Askelânî (öl. 1449), Enbâu'l-ğumr fî ebnâi'l-umr adlı eserinde, Memlûk Devleti'nin hem Osmanlı hem de Memlûk coğrafyasını tehdit eden Timur istilasını bir rüzgâr gibi geçici, Osmanlı varlık1nı bir derya gibi kalıı ise gördüğünü vurguladıktan sonra şöyle der: “ İbn Haldûn'un pek çok kez şöyle dediğini işittim: Mısır Devleti için Osmanoğlu'ndan başka korkulacak bir tehlike' yoktur." İbn Haldûn (öl. 1406) gibi tarihi iyi okuyan bir düşünürün, henüz İstanbul'u fethetmemiş; üstelik Ankara savaşında Timur’a yenilmiş ve fetret devrini yaşayan Osmanlı Devleti'ni kalıcı görmesi -ki İbn Haldûn'un tespitinin ne kadar doğru olduğuna tarih şahittir- için ne tür bir gözleme dayandığını düşünmek, tarihte kalıcı ile geçici olanı idrak etmek için iyi bir başlangıç olabilir. Başka bir deyişle, İbn Haldûn'un Osmanlı için karar verirken yaslandığı ilkeleri/illetleri yakalamak, günümüzde Amerika Birleşik Devletleri ve hempalarının -şimdilerde buna NATO diyorlar- yeryüzünde estirdikleri terörün ve kalkıştıkları işgalin kalıcı mı, geçici mi olduğunu tespit etmek için elzemdir. Öyleyse sorumuzu şöyle dile getirilebiliriz: Bir siyasî irâdeyi yeryüzünde kalıcı veya geçici kılan nedir/nelerdir?" ${ }^{33}$ Yalnızca adâlet üzerine kurulu bu siyaset, meşveret ile yürür, liyâkat ve ehliyete dayanır, nesne ile teması sürekli kılar, bilgi ile bunu üreten bilgine saygı gösterir, insanı önceleyen ve tebcil eden, insanı ümit olarak gören bir çerçeve inşa eder." ${ }^{34}$ İbn Haldun'un adalet ile kalıcılık arasındaki kurduğu ilişki Osmanlı'nın siyasi iktidar olma yolunda başvuracağı bir araç olmaktan ziyade adaletin imparatorlukla izdivacının tarihte kalıcılığın teminatı olabileceği şekilde de okunabilir. Zira adalet güçsüz tahakkuk edemeyeceği gibi, adaletin olmadığı gücün de tarihte kalıcı olma imkânı yoktur.

Osmanlı imparatorluğu özelinde imparatorluğu kuran inanç (itikat), sürdürülmesini sağlayan ise adalettir (fıkıh). İnancı da adaleti de mümkün k1lan ise insan ve bilgidir. Ancak ulus-devletle sermaye-devlet, yani sermaye ile devletin birliği tesis olunur. Mutlak monarşilerde de kapitalizm devlet tarafından desteklenir, devlet bir aktör olarak ekonomik sürecin içindedir. ${ }^{35}$ Çünkü ulus-devlet, doğası itibarıyla farklı olan şu iki öğenin bir araya getirilmesidir: ulus ve devlet. Fakat ulus-devletin ortaya çlkabilmesi için önce sermaye-devletin ortaya çıkmış olması, yani sermaye ile devletin bir araya getirilmiş olması gerekir..$^{36}$ Ulus hassasiyeti kan bağına dayalı bölgesel ve dilsel topluluklar temeline dayanır. Fakat ulusun sırrı bunların hiçbirinde değildir:

33 Fazlıoglu, a.g.e. s. 15. 
Ulus sırf böyle toplulukların varlığı nedeniyle oluşmaz, ancak sermaye-devletin belirmesinden sonra ortaya çıkar. ${ }^{37}$

Ulus, mutlak egemenin bir burjuva devrimiyle devrilmesinden sonra, her birey özgürlük ve eşitliğe sahip olunca ortaya çıkar. Fakat bunlar tek başına yeterli değildir. Bireysel özgürlük ve eşitliğe ek olarak bir dayanışma duygusuna da ihtiyaç vardır. Sözgelimi Fransız Devrimi’nin sloganı “Özgürlük, eşitlik, kardeşlik”tir. Burada özgürlük ve eşitlik akıldan türeyen kavramlardır, fakat kardeşlik başka bir düzene aittir: Bireyleri birbirlerine bağlayan bir dayanışma duygusuna delalet eder. Bir ulusun böyle bir dayanışma duygusuna ihtiyacı vardır. Aile ya da kabile topluluğu içindeki sevgiden farklı, daha önceki bağlarından kopmuş insanlar arasında doğan yeni bir dayanışma duygusudur bu. ${ }^{38}$

Ulusu tek başına ekonomik ya da siyasi çıkar bağlamında anlayamayız: Metafizik bir boyutu da vardır. Fakat buradan, ekonomi ya da politikadan farklı olarak, ulusun ruhsal bir düzlemde var olduğu sonucu çıkmaz. Buradan çıkan sonuç basitçe, ulusun karşılıklılığa, yani bir meta ekonomisinden temellenen mübadele tarzından farklı bir mübadele tarzına dayandığıdır. Ulus, meta mübadelesi ekonomisinin temellerini sarstığı komünal topluluğun hayali yeniden tesisidir. Sermaye-devlette olmayan duyguyu aşılar. ${ }^{39}$

Yine bu bakımdan, ulus bir hayali cemaattir. Kapitalist ekonominin ürettiği gerçek eşitsizlikler, özgürlük ve eşitliğin olmaması, ulusta hayali bir biçimde telafi edilir ve çözüme bağlanır. Dahası ulus karşılıklılık ilkesine dayanan bir komünal topluluk hayalini gerektirir ve bu devletin yönetme aygıtlarından ayrıdır. Dolayısıyla ulus bir eşitlik talebidir, devlet ve sermayeye karşı eleştirel bir protestoyu üstü kapalı olarak içinde barındırır. Fakat aynı zamanda, sermaye-devletin yarattığı çelişkilerin hayali bir çözümü olan ulus, sermaye-devleti çöküşten de korur. Yani ulus doğası itibarıyla muğlaktır. Argümanıma, ulus-devlet olarak adlandırdığımız şeyin aslında Sermaye-Ulus-Devlet olarak anlaşılması gerektiğini ifade ederek başlamıştım. Kapitalist ekonomi (duyarlık) ve devlet (idrak), ulus (hayal gücü) tarafından bir arada tutulur. ${ }^{40}$

Emperyalizm bir ulus-devletin başka bir ulusu imparatorluğun yönetme ilkesi olmaksızın tahakküm altına almasıdır. Osmanlı İmparatorluğu'nu parçalayan Batılı güçlerin çok geçmeden Arap milliyetçiliği gibi bir tepkiyle

37 Karatani, a.g.e. s. 291. 
karşılaşmasının nedeni budur. ${ }^{41}$ Sonuç olarak imparatorluğun hâkimiyeti kabile ayaklanmalarına neden olurken, emperyalizmin hâkimiyeti milliyetçiliğe yol açar. Böylece emperyalizm -yani bir ulus-devletin başka halklar üzerindeki hâkimiyeti- hiç de böyle bir niyeti olmamasına rağmen nihayetinde yeni uluslar yaratır. ${ }^{42}$ Bir ulus-devlet hiçbir zaman yeni açılmış beyaz bir sayfa üzerinde kurulmaz. Hâlihazırda var olan bir toplum zemininde doğar. ${ }^{43}$

Ulus-devletin tarihin sonunda bulunan nihai birim olmadığı da açıktır. Modern ulus-devlet eski dünya imparatorluklarının olumsuzlanması ve parçalanmasından doğmuştur; fakat bu, eski dünya imparatorluğuna ve burada var olan kültürel ve dinsel komünalliğe geri dönme itkisini daima barınd1racağı anlamına gelir. Böyle bir durumda, eğer tek bir ülke imparatorluğu yeniden kurma girişimine ön ayak olursa, sonuç ancak emperyalizm olabilir. ${ }^{44}$ Geçmişini reddederek, sıfırlayarak, sıfır noktasından yeni, yepyeni bir toplum “yaratma” düşü kurmak Tanrı olmaya soyunmaktır. Bedeli travmatik bir fiyaskodur. Politik terimlerle dile getirmek gerekirse modern zamanların bütün "büyük” devrimleri “Aydınlanma projeleri”dir. Yirminci yüzyılın bütün devrimleri büyük "darbe"lerdir ve "devrim" radikal darbedir. ${ }^{45}$ Ulus-devlet geçmişi reddetmeye, tarihin sıfır noktasına dönmeye yönelik devrimci bir hamle olarak taravmatik bir fiyaskoya davetiye çıkarmaktadır.

\section{İmparatorluğun Halkı versus Ulus-devletin Kitlesi}

Ulus-devletin halkı Fransız tıp asıllı bir antropolog olan Gustav Le Bon'un (1841-1931) Kitleler Psikolojisi ${ }^{46}$ adlı kitabında anlattığı kitledir. Sadece özel zamanlarda bira araya gelen, şiddete ve tahrike mütemayil, kendi kişiliği ve kimliğinden bihaber anonim bir kitledir. Bilinçaltı ile hareket eden organize bir sürüdür. Zihniyetin tek-tipleşmesi kanununa tabidir. Bunun için ulus-devletin yaşayan bir halkı değil, cesetleri vardır. Ancak aynı kitle millet olmaya çalışan halkları körü körüne boyun eğen koyunlar olarak nitelemekten de geri kalmaz. Bu anlamda mesela “Türk milletinin koyunluğunu eleştirenler, koyun kelimesinin halk arasında çağrıştırdığı, ama hiç de menfî

41 “Batı Avrupa ve Rusya’nın saldırı tehdidi altındaki Osmanlı ‘'̇mparatorluğu’, imparatorluğunu bir ulus-devlete dönüştürmeye çalıştı, fakat bu çaba en nihayetinde imparatorluğun çok sayıda ulusa bölünmesiyle sonuçlandı. Osmanlı toplumu Batılılaşma çabası güderken, aynı zamanda Batı’ya karşı direnmek için İslam'da bir temel bulma arayışındaydı. Günümüzün baskın İslamcılığı büyük ölçüde bu dönemin bir ürünüdür." Karatani, a.g.e. s. 310.

42 Karatani, a.g.e. s. 311.

43 Karatani, a.g.e. s. 311.

44 Karatani, a.g.e. s. 374.

45 Hüsamettin Arslan, “Aydınlanmış Ulus-Devletten Demokratik İmparatorluğa”, Kritik Dergisi, Yıl: 1, Sayı: 8, 2016.

46 Osmanlıcaya Illm-i Ruh-i İçtimai adıyla tercüme edildi. 
olmayan itaat etme, boyun eğme cihetini öne çıkartırlar. Ancak unutulan nokta, bu eleştiri ancak ve ancak başka bir cihet adına yapılırsa anlamlıdır. Başka bir deyişle, rahatsızlık veren itaat etme ve boyun eğme eylemleri değil, kime itaat edildiği ve nereye boyun eğildiğidir. Çünkü sömürgeci kapitalist güç, kendine itaati ve boyun eğmeyi zorlaştırdığı, direnmeyi sürdürdüğü için Türk'ün koyunluğunu yani mensubiyetini tahkir eder." ${ }^{47}$ Buna göre ulusal bir kitle oluşturmak isteyenler buna karşı çıkanları koyun bir halk diye nitelendirirler. Anacak sorun koyun olmak değil, hangi sürüye mensup bir koyun olunduğundadır. "Çünkü sömürgeci kapitalist gücün daveti kendi sürüsüne katmak üzerinedir; aralarında sadakatin, şefkatin, birbirine muvafakatin, ülfetin ve itaatin olmadığı, birbirine sürtünmekten, temas etmekten kaçınan, birbirine menfaati değil faydası dokunan, millet anlamında değil yığın anlamında bir sürü. Ancak böyle bir sürü üretim-tüketim denklemi içinde yaşayabilir, sağılabilir, yönlendirilebilir. Böyle bir sürü bilgi ve adalet yani nizâm-1 âlem için savaşmaz, yakıp yıkar, yer-içer-sevişir." ${ }^{48}$ Yakın tarihimiz Türk milletinin sürü olma, yani sadakatin, şefkatin, birbirine muvafakatin, ülfetin ve itaatin olduğu, birbirine sürtünmekten, temas etmekten hoşlanan, birbirine menfaati dokunan, birbiri için yaşayan, kısaca birlikli ve dirlikli olmaya çallşan biçiminde özetlenebilecek sıfatlarını törpüleme tarihidir.

Ulus-devletin kitlesine karşın imparatorluk halkının kendi bütünlüğünü, sadakatini, şefkatini ve ülfetini koruduğu bir hukuku vardır. Zira bir dünya-imparatorluğuna kapsadığı tek tek toplulukları aşan bir hukuk ancak onları bir arada tutabilir. Bu hukuk yalnızca çeşitli kabile ve devletlere nasıl hükmedeceğini değil, kendi “arasındakini” nasıl sağlama alacağını da göz önünde bulundurması gerekir. ${ }^{49}$ Kendi aralarında bir hukuku olmayanlar kitlelerdir. Kitle olmak hukuksuz, herhangi bir şeye itaat etmeyen, varlığını ve gücünü sadece içinde yer aldığı kalabalıktan alan, ilkesiz bir güruh anlamına gelir. Bununla birlikte Locke ve burjuva devrimlerinden sonra ortaya çıkan filozoflar her bireyi özne olarak görüyor, “toplum sözleşmesi” anlayışlarını bu bireylere (ulus kimliğine sahip halka) dayandırıyorlardı. Fakat Hobbes için egemenin kendisi hariç herkes egemenin tebaasıydı. Kolektif ulusal özne, öznelerin mutlak egemene tabi olmasıyla birlikte doğmuştu. ${ }^{50}$

47 Fazlığlu, Akıllı Türk Makul Tarih, s. 46.

48 Fazlıoğlu, a.g.e. s. 46.

49 Karatani, a.g.e. s. 160.

50 Karatani, a.g.e. s. 243. 


\section{İmparatorluğun Bakiyesi Türkiye'de Ulus-devletin Bunalımı}

İmparatorluğun bakiyesi ülkelerin ulus-devlet tecrübeleri bunalımlarla doludur. Bunalım bir tercih değil bir kaderdir, geçici ve dönemsel değil, kangren gibi kalıcıdır. Bu anlamda Türkiye'nin bunalımı bir mukadderattır. İmparatorluk kumaşından ulus-devlet elbisesi dikmek istemiştir. Ortaya giyilebilecek bir elbise çıkmadığı gibi kumaş da her geçen gün ziyan olmaktadır. Ortada bir tuhaflık ve olağanüstü bir durum vardır. Türkiye Cumhuriyetinin, sıra dışı şartlarda ve farklı öncelikler esas alınarak kurulması anlamsız değildir. “Osmanlı'nın uzun bir gerileme ve çöküş döneminden sonra tarih sahnesinden çekildiğini gören ve bu tarihi kırılmaya ve travmaya bir cevap olarak Cumhuriyeti kuran kadrolar, vatansız, milletsiz ve devletsiz bir bekanın mümkün olmadığını görmüşlerdi. Fakat kurdukları Cumhuriyet bir kriz dönemi ideolojisine dayanıyordu. Krizin merkezinde imparatorluktan ulus-devlete, milletten ulusa, dini bir gelenekten seküler bir moderniteye geçişin sancıları vardı." ${ }^{51}$ Söz konusu sancılı durum gittikçe bir travma haline dönüştü. Zira din ve millet gibi yerli yerine oturtulamayan iki büyük kavram ulus-devletin gölgesinde bir imkân, gelenek ve potansiyel bir güç ve dinamizm unsuru olmaktan çıkarak birer tehdit olarak görülmeye başlanmıştı. Bu ortamda dini yaşamın özgürleşmesi irticaya, kontrol altına alınmamış millet unsurlarının varlığı ise bölücülüğe yol açacağı korkusuyla acil önlemler almaya girişti. Dinin potansiyel tehdidine seküler-modernleşmeci tepkilerle, farklı milletlerin kontrol edilemeyeceği korkusu ile etnisiteye dayalı ulus-devlet ve toplum tasavvurunun sinırları çizilmeye başlandı. ${ }^{52}$ Haliyle ortaya etno-seküler bir refleks çıktı. Bu etno-seküler reflekse göre "din, seküler modernleşmenin önünde bir engeldi çünkü dünyevi bir varlık tasavvuruna ve insan anlayışına imkân vermiyordu. Sosyal planda ise dinin etnik-kimliklerin üzerinde bir aidiyet sunması, etno-seküler ulus-devlet projesine bir engel teşkil ediyordu. Dinin bir 'araz' olarak gördüğü etnisiteler mutlak ve kurucu bir değer haline geldiğinde, öteki etnisitelerle çatışması kaçınılmazdı..$^{53} \mathrm{Bu}$ durumda Cumhuriyet mühendisleri için Anadolu sathında “Türk”ten başka herkes bir tehditti ve ortadan kaldırılmalıydı. Buradaki 'Türk' de şüphesiz yeni bir kurgudan ibaretti. Millete değil ulusa atfen kullaniyordu. Sonunda bu kurguya ve bağlama aykırı olan herkes hasım ilan edildi. Mesela "İttihat ve Terakki kadroları ve Cumhuriyetin kurucu elitleri, Osmanlı'daki anasır milliyetçiliğine cevap olarak etno-seküler Türk milliyetçiliğini savundu. Ayrıca merkezi kontrolü ve güvenliği sağlamak adına kozmopolit ve çoğulcu

51 Kalın, a.g.e. s. 31.

52 Kalın, a.g.e., s. 33.

53 Kalın, a.g.e., s. 35. 
toplum yapısının yerine homojen, merkeziyetçi ve güvenlik-eksenli bir devlet ve toplum yapısı inşa etmek istedi. "Millet" kelimesinin geleneksel manasının ihtiva ettiği geniş semantik alan, yeni ulus-devlet modeliyle daraltıldı ve mekanikleştirildi." ${ }^{54}$ Semantiğin daraltılması ufkun ve derinliğin yokluğunu da beraberinde getirdi. Devlet ile millet arasındaki organik bağlar yerini mekanik ilişkilere bıraktı.

Devletin mekanik bir tarzda kurgulanması devletin milleti terbiye ettiği bir sürece dönüştü. Sürecin sonucunda ise "Cumhuriyetin "ulus-devlet" olma projesi, kısa sürede bir "devlet-ulus” olma projesine dönüştü." ${ }^{55}$ Zaten kurgulanmış bir ulus tabandan evrim yoluyla değil, tavandan devrim yoluyla mümkün olabilirdi. Devlet-ulus olarak milleti terbiye etmek ve yeniden yaratmak için devlet, her türlü değişimin ve gelişmenin yegâne patronu haline geldi. Çünkü muhayyel bir millet yaratmak için devlete ihtiyaç vardı, modern ulus-devlet ise bunu sadece yegâne patron olan devlet yapabilirdi. ${ }^{56}$ Burada şu hususun altını önemle çizelim ki, bu söylenenlerden gerçekte "Türk milleti" diye bir şeyin olmadığı sonucu çıkarılmamalıdır. Tarihsel olarak Türk boylarına kadar giden, Türkçe konuşan, Türkçe metinler yazan, kendini Türk olarak tanımlayan bir insan topluluğu hep var olmuştur. Bununla birlikte modern ulus-devletlerin tanımladığı şekliyle bir “Türk milleti”nin kurgulanışı, 20. yüzyılın başlarında Türkiye'nin Cumhuriyeti kuruluş dönemine denk gelir. Aynı şey Araplar, Kürtler, Arnavutlar, vd. için de geçerlidir. Çünkü ortada henüz modernite diye bir şeyin olmadığı zamanlarda bir topluluğu millet yapan şey etnik köken, ırk yahut dilden ziyade din, adalet, düzen, erdem gibi temel ve evrensel değerler olduğu, millet dediğimiz şeyin bu unsurların üzerine kurulu bir kültür ve medeniyet kodu olduğu kabul edilirdi. Ulus- devlet ise bu unsurların varoluşunun aktörü ve teminatı olarak yalnızca kendisini görür. Hatta kendisini bunların üstünde bir konuma yerleştirir. Bunun içindir ki meşruiyetin merkezi olarak milleti, tarihi yahut geleneği değil kendisini adres gösterir. Şüpheniz bu türden bir zihniyet, devlet ile millet, siyaset ile devlet, yöneten ile yönetilen, şehir ile taşra, merkez ile çevre arasında derin uçurumların doğmasına zamanla bunların arasındaki derin bağların kopuşuna neden olmuştur. ${ }^{57}$ "Cumhuriyet elitlerinin ulus-devlet eliyle gerçekleştirmeye çalıştığı modernleşme projesi, bu yüzden derin bir yabancılaşma tarihidir. Saf medeniyet ve muhayyel Türk tipolijisine bir türlü uymayan Anadolu insanı, Türk'üyle, Kürt’üyle, Müslümanıyla, 
Hristiyanıyla, bu tek-tipleştirme projesine karşı genellikle mesafeli olmuş, bazı dönemlerde aktif ve pasif direniş göstermiştir." ${ }^{58}$ Zira imparatorluğun kumaşından bu türden elbiselerin çıkması mümkün değildir, eğer böyle bir elbise bir şekilde dikilmiş ve zorla bir milletin üstüne giydirilmeye çalışılmışsa milletin direnişi ile karşılaşılması mukadderdir.

\section{Sonuç}

$\mathrm{Bu}$ makalede imparatorluk ve ulus-devlet gramer ve mantık metaforundan hareketle yeniden yorumlanmaya ve tahayyül edilmeye çalışılmıştır. Zira ister tarihsel bir olguyu ister zihinsel bir kavramı anlama ve yorumlama faaliyeti olmuş bitmiş bir duruma değil, yeniden okuma, anlama ve yorumlama sürecine atıfta bulunur. Bu kontekste gramer ve mantık metaforları bir imkâna ve zorunluluğa işaret edecek şekilde kullanılmıştır. Gramer hep bir imkân olarak karşımıza çıkar. Gramer dilin kemiği olarak kendisiyle anlamaya çalıştığımız metaforun yaşayan haline işaret eder. Bu anlamda gramer olarak imparatorluk bir imkâna ve de facto bir duruma çağırır bizi. Ulus-devlet ise değişmezlik ve zorunluluk olarak bizi a priori mekanik bir duruma zorlar. Söz konusu gramer-mantık metaforun kendisini inşa ettiği zemin ise ontoloji ve ideoloji olmaktadır. Buna göre imparatorluk ontolojik bir gramer olarak tahayyül edilmiş, farklılık, derinlik, otantiklik, adalet, liyakat, esneklik, gelenek, hetorejenlik ve kozmopolit kavramları ekseninde de facto bir durum olarak konumlanmıştır. İmparatorluğa atfedilen bu niteliklerin olgusal ve tarihsel varlığına ilişkin zaman zaman örnekler verilse de asıl meselemiz imparatorluklar değil imparatorluktur. Diğer yandan ulus-devlet ise, benzerlik, eşitlik, yapaylık, elitlik, katılık ve homojen kavramları ekseninde a priori bir zorunluluk dayatması olarak konumlanmıştır. İmparatorluktan ulus-devlete geçişin bir ufuk ve eksen küçülmesi, felsefi olarak ontolojiden kopuşu, sosyolojik olarak halktan kitleye geçişi, ekonomik olarak paylaşımcı ve dayanışmacı yapıdan sermayenin merkezileştiği kapitalist sisteme dönüşü, etik olarak adaletten ayrılışı, politik olarak ise milletten etno-seküler ulusçuluğa geçişi temsil ettiği gösterilmeye çalışılmıştır.

Bugünün vülger imparatorluk kurgusu, imparatorluğun kendisine odaklanmaktan ziyade onu saltanat, veraset, fetih, kılıç, savaş, hilafet, harem, saray, despot ve otoriter nitelikleri ile anmaktadır. Hâlbuki imparatorluk geçmişin tecrübelerinin değişmez taklitleri değil, geleceğin yeniden inşası yolunda bir tahayyüldür. Vülger imparatorluk kurgusu farklılık, derinlik, otantiklik, adalet, liyakat, esneklik, gelenek, hetorejenlik ve kozmopolit kavramları gibi

58 Kalın, a.g.e. ss. 64-65. 
kavramları anlayabilecek düzeyde değildir. İster imparatorluktan yana olsun isterse karşı olsun imparatorluk kavramından anladığı tarihsel olanı taklit etmek veya bu taklide karşı çıkmaktır. Hâlbuki imparatorluk tarihsel olanı taklit değil, tarihi olanı tahayyül etmektir. İmparatorlukların tarihsel tecrübeleri değişmiş, dönüşmüş, evrilmiş veya devrilmiş olabilir ama bir tahayyül olarak imparatorluk kendisini karakterize eden kavram ve ilke bağlamında her daim karşımızda, hafızamızda ve idealimizde yaşayan bir gelenek olarak de facto var olur.

Son olarak imparatorluk ve ulus-devlet karşılaştırması adeta bir laboratuvar gibi karşımızda duran imparatorluk bakiyesinden ulus-devlete geçiş yapmaya çalışan Türkiye üzerinden çok yüzeysel anlamda birkaç fırça darbesiyle okunmaya çalışılmıştır. Burada da temel meselemiz aslında somut tarihsel ve olgusal bir durum olarak Türkiye'nin yaşadığı bunalımlar değil, söz konusu bunalıma neden olan zihniyet ile ilgilidir. Çalışmamız konu edindiği iddiaları vaz etme ve temellendirme açısından yetersiz olsa da bu türden konuların ayrıntılı bir şekilde gerekçelendirmesi bir makalenin sınırlarını fazlasıyla aşacağından şimdilik bununla yetiniyoruz. Bununla birlikte bu makale bu türden konuların salt epistemik ve objektiflik düzleminde anlaşılmasının her zaman ve zeminde doğru olmayabileceğinin bir işareti olarak yeni denemelerin ve ufukların bazen ele aldığımız konunun tam kalbine götürebileceği ihtimaline bel bağlayarak yazılmıştır.

\section{Kaynakça}

AKGÜN, Mehmet, Materyalizmin Türkiye’ye Girişi, Elis Yayınları, Ankara, 2005.

ALPER, Ömer Mahir, Osmanlı Felsefesi Seçme Metinler, Klasik Yayınları, İstanbul, 2015.

ALTHUSSER, Louis, İdeoloji ve Devletin İdeolojik Aygıtları, çev. Yusuf Alp, Mahmut Özışık, İletişim Yayınları, İstanbul, 2002.

ARSLAN, Hüsamettin, “imparatorluğun Dansı”, Derin Tarih, Nisan, 2017.

ARSLAN, Hüsamettin, “Aydınlanmış Ulus-Devletten Demokratik İmparatorluğa”, Kritik Dergisi, Yıl: 1, Sayl: 8, 2016.

ARSLAN, Hüsamettin, “Mütercimin Önsözü”, İnsan Bilimlerine Prolegomena, der-çev. Hüsamettin Arslan, Paradigma Yayınları, İstanbul, 2002.

ARSLAN, Hüsamettin, Jöntürkler, Jönkürtler ve Muhafazakârlar Meçhul Okurla Söyleyişiler, Paradigma Yayınları, İstanbul, 2012.

BAYRAKTAR, Levent, "Bergsonculuğun Türkiye’ye Girişi ve Illk Temsilcileri”, Felsefe Dünyası, Sayı: 28, 1998, ss. 62-72.

DEMiR, Remzi, Philosophia Ottomanica Osmanlı Imparatorluğu Dönemi'nde Türk Felsefesi, (Eski Felsefe), Cilt: I, Lotus Yayınları, Ankara, 2005. 
DiNÇER, Ömer, Siyasetnameleri Yeniden Okumak, Bir Yönetim Bilimci Gözüyle Geleneksel Siyasi Düşünce, Klasik Yayınları, İstanbul, 2018.

DURALı, Ş. Teoman, Çağdaş Küresel Medeniyet Anlamı, Gelişimi Konumu, Dergâh Yayınları, İstanbul, 2016.

FAZLıOĞLU, ỉhsan, Akıllı Türk Makul Tarih, Papersense Yayınları, İstanbul 2014.

FAZLıOĞLU, ìhsan, Derin Yapı İslam-Türk Felsefe-Bilim Tarihinin Kavramsal Çerçevesi, Papersense Yay. İstanbul, 2014.

FAZLıOČLU, ìnsan, Kayıp Halka İslam-Türk Felsefe-Bilim Tarihinin Anlam Küresi, Papersense Yay. İstanbul, 2014.

FAZLIOĞLU, İhsan, Nazari Ufuk İslam-Türk Felsefe-Bilim Tarihinin Zihin Penceresi, Papersense Yay. İstanbul, 2016.

GENCER, Bedri, İslam'da Modernleşme 1839-1939, Doğu Batı Yay. Ankara, 2012.

GÖÇEK, Fatma Müge, Burjuvazinin Yükselişi, imparatorluğun Çöküşü: Osmanlı Batılılaşması ve Toplumsal Değişme, Ayraç Yayınları, Ankara, 1999.

GUTAS, Dimitri, Arapça Düşünce Yunanca Kültür Bağdat'ta Yunanca-Arapça Çeviri Hareketi ve Erken Abbasi Toplumu, çev. Lütfi Şimşek, Kitap Yayınları, İstanbul, 2003.

HAROLD, J. Laski, A Grammar of Politics, London: Allen \& Unwin, 1925.

KALIN, İbrahim, Akıl ve Erdem Türkiye'nin Toplumsal Muhayyilesi, Küre Yayınları, İstanbul, 2013.

KARATANi, Kojin, Dünya Tarihinin Yapısı \& Üretim Tarzlarından Mübadele Tarzına, çev. Ali Karatay, Metis Yayınları, İstanbul, 2019.

KESKINTAŞ, Orhan, Adalet, Ahlak ve Nizam Osmanlı Siyasetnameleri, İletişim Yayınları, İstanbul, 2017.

KORLAELÇi, Murtaza, Pozitivizmin Türkiye’ye Girişi, İnsan Yayınları, İstanbul, 1986.

KÜÇÜKALP, Kasım, “Ötekine Yönelik Etik Refleksiyonun İmkânı Olarak Adalet”, Ahlak ve Başkası Modern Felsefede ve İslam Düşüncesinde Öteki, Ed. Lütfü Sunar \& Selami Varlık, Nobel Yayınları, İstanbul, 2017.

MAKDISI, Georg, İslam’ın Klasik Çağında Din, Hukuk, Eğitim, çev.: Tuncay Başoğlu, Klasik Yayınları, İstanbul 2019.

MORAN, Dermot, "The Destruction of Destruction: Heidegger's Versions of the History of Philosophy", ed. Karsten Harries, Christoph Jamme, Martin Heidegger: Politics, Art and Technology, Holmes \& Meier, New York, 1994.

MÜNKLER, Hefried, Imparatorluklar Eski Roma'dan ABD’ye Dünya Egemenliğinin Mantığı, çev.: Zehra Aksu Yılmazer, İletişim Yayınları, İstanbul, 2012.

NEGRI, Antonio, Porselen Yapımı Politikanın Yeni Bir Grameri Için, çev.: Elyasa Koytak, Monokl Yayınları, İstanbul, 2013.

ÖZEL, Mustafa, Roman Diliyle Siyaset, Küre Yayınları, İstanbul, 2018.

RORTY, Richard, Olumsallık, İroni ve Dayanışma, çev.: Mehmet Küçük - Alev Türker, Ayrıntı Yayınları, İstanbul, 1995.

SAID, Edward, Şarkiyatçılık (Batı'ıı şark Anlayışları), Çev. Berna Yıldııım, Metis Yayınları, İstanbul 2017.

SANDERS, Barry, Kahkahanın Zaferi Yıkııı Tarih Olarak Gülme, Çev. Kemal Atakay, Ayrıntı Yayınları, İstanbul, 2001. 
86 | Mehmet Ulukütük

SCHMITT, Carl, Siyasal Kavramı, çev.: Ece Göztepe, Metis Yayınları, İstanbul 2006.

TOKU, Neşet, Türkiye'de Anti-Materyalist Felsefe -Spirütalizm Illk Temsilciler-, Beyan Yayınları, İstanbul 1996.

ULUKÜTÜK, Mehmet, “Dinin Grameri Versus Felsefesinin Mantığı: İslam Düşüncesinde Dinî ve Felsefî Epistemeler Gerilimin Mantıksal ve Gramatik Temelleri”, İönü Üniversitesi ilahiyat Fakültesi Dergisi [Mesned ilahiyat Araştırmaları Dergisi], cilt: III, sayı: 2, ss. 135-162.

ULUKÜTÜK, Mehmet, "íslam Düşüncesinde Tercüme Faaliyetleri: Hermeneutik ve Bibliyografik Bir Katkı”, İnönü Üniversitesi, Illahiyat Fakültesi Dergisi [Mesned Illahiyat Araştırmaları Dergisi], Sayı:2, Yıl:1, 2010, ss. 249-288.

ULUKÜTÜK, Mehmet, "Çağdaş Türkiye'de Felsefenin Osmanlıcasını Keşfetmek: Bir Literatür Değerlendirmesi", Muhafazakâr Düşünce Dergisi, Yıl: 15, Sayı: 54, 2018, ss. 201-228.

ÜNLÜ, Barış, “imparatorluk Fikrinin Gelişimi”, Ankara Siyasal Bilgiler Fakültesi Dergisi, Cilt:65, Sayl:3, 2012: 237-266.

YÜCESOY, Hayrettin, Ortaçağ İslam'ında Mesihçi Inançlar ve İmparatorluk Siyaseti Dokuzuncu Yüzyııın Başlarından Abbasi Hilafetine Kadar, çev. Ahmet Demirhan, Klasik Yayınları, İstanbul, 2016. 